Наташа Васиљевић

UDC: 02:004.738.5

Вука Јеремић

Универзитетска библиотека

„Светозар Марковић“

DOI: $10.18485 /$ dh.2015.1.ch13

\title{
БИБЛИОТЕКЕ И ДИГИТАЛНА ХУМАНИСТИКА: МЕЂУСОБНИ УТИЦАЈИ И ПЕРСПЕКТИВА
}

\begin{abstract}
Сажетак
После краћег терминолошко-теоријског осврта на различите делатности библиотека које унапређују научни рад у области дигиталне хуманистике, дати су неки примери таквог њиховог ангажмана, заступљени у претходних десетак година. Ова врста делатности у библиотекама превасходно је развијана преко различитих облика програмске и пројектне сарадње са другим научним институцијама и чешће била усмерена на заштиту културне баштине него на креирање оригиналних научних радова, или пак на унапређење наставно-научног процеса.

Рад разматра начине на које је Универзитетска библиотека „Светозар Марковић“до сада учествовала у пројектима који су посредно или непосредно везани за област дигиталне хуманистике, али и оне које је могуће имплементирати и у тренутним, релативно неповољним околностима, у циљу проширења квалитета услуга и јачања веза са универзитетском заједницом. Водећи рачуна о одрживости пројеката у реалном друштвеном и академском окружењу и савременим трендовима научно-истраживачке делатности, предлаже се неколико мера које подразумевају рационално коришћење постојећих ресурса и сврсисходно креирање нових, стално редефинисање приоритета и паралелни ангажман у Библиотеци и ван ње.
\end{abstract}

Кључне речи: библиотеке, дигитална хуманистика, анализа података

Није згорег почети са терминолошким питањима када се покушавају промислити теме које заокупљају пажњу широког спектра стручњака из различитих области, као што је то случај са дигиталном хуманистиком. Ваља истаћи чињеницу да је и традиционална хуманистика појам који има другачије значење у различитим језицима и културама. Док се у српском језику хуманистика раније по правилу 
дефинисала као збир вештина и наука које човека чине човеком, превасходно класичне грчко-римске студије, ослањајући се на француску традицију која се искључиво ограничавала на изучавање класичног периода ${ }^{1}$, Британска енциклопедија под хуманистиком подразумева оне научне дисциплине које изучавају људе и њихову културу примењујући аналитичке и критичке методе испитивања изведене из јединствене способности људског духа да се искаже 2 . Управо се у дефиницији Британске енциклопедије назире наговештај нејасне линије раздвајања хуманистичких и друштвних наука, данас присутан у свакодневном значењу чак и код оних који се одважују да се баве дефинисањем дигиталне хуманистике, присутан и у дефиницијама из новијих речника страних речи у Србији. ${ }^{3}$

Проблем са дефинисањем дигиталне хуманистике као научне дисциплине лежи у непостојању јасних граница истраживања, посебног предмета, нити методолошке строгости, због чега се у дефиницијама више користе појмови „област“ или „поље“ истраживања (а у Другом манифесту то експлицитно више „није јединствено поље већ низ конвергентних пракси“4), и инсистира на могућностима, предностима и променама у односу на традиционалну хуманистику. Дефиниције су зато често недовољно јасне и више-мање описног карактера, и подложне примедбама. Вероватно највише негодовања изазвала је формулација Стивена Ремзија ${ }^{5}$ да је дигитални хуманиста онај који нешто прави (програмира, кодира), а не онај који промишља, чиме је у фокус уместо идеја стављен објекат - нешто опипљиво, што се може продати, разменити, што припада сфери вештине а не теорије. У оквиру таквог схватања размена идеја своди се на мрежну испоруку садржаја, при чему се провлачи уверење да читање, контемплација, креативно и критичко мишљење у савреме-

1 Док се у издању речника Micro Robert из 1989 термин дефинише као,,проучавање грчког и латинског језика и књижевности", Le Robert illustré d'aujourd'hui из 1996. године наводи идентичну дефиницију, али овај пут са ознаком застарелости. http://www.britannica.com/topic/humanities

Клајн, Иван, Милан Шипка Велики речник страних речи и израза. Нови Сад: Прометеј, 2008, стр. 1440 : „општи назив за науке које проучавају друштвене односе и духовну активност људи“ http://dhdebates.gc.cuny.edu/debates/part/2 
ном свету зацело не могу бити ни од какве користи, па и хуманистичке науке треба прилагодити потребама таквог света. Дакле, у овом и сличним објашњењима „бескорисност“ традиционалне хуманистике покушава се превазићи њеним удруживањем са технологијом, чиме јој се додаје нешто од озбиљности и значаја „правих наука“. Са друге стране, поред ове, уистину доминантне тенденције да се уз помоћ дигиталног окружења и дигиталних алата радикално промени метод истраживања, постоји и она радикално супротна да се хуманистика треба посветити теоријском промишљању утицаја нових технологија на живот човека у целини, како наводи Пол Спенс. ${ }^{6}$

Посебно занимљиво у вези са дефиницијама дигиталне хуманистике је што њихове кључне речи нису ни дигитално ни хуманистика већ интердисциплинарност, отвореност и колаборативност, визуализација података. ${ }^{7}$ Компликације око дефинисања дигиталне хуманистике проистичу и из њене дисциплинарне хетерогености и институционалног диверзитета ${ }^{8}$ као и многострукости начина на који су ангажоване информационе технологије. Осим тога, утемељење дигиталне хуманистике настојало се спровести кроз манифесте, а не кроз курикулуме, при чему се изгубило из вида (или можда није?) да су манифести, програмски текстови и прогласи - карактеристични за револуције и покрете, били они политички или уметнички. Са нарочитом намером да се релаксира „преозбиљна и заморна“ академска фразеологија и задобије нешто јеретичког шарма, у тим манифестима коришћен је свакодневни „блогерски“ речник и стил. Други манифест, на пример, даје јасна упутства: не кукај, коментариши, ангажуј се, разгласи, пусти идеју, придружи се, продужи даље. ${ }^{9}$

$6 \quad$ Spence, Paul. "Centros y fronteras: el panorama internacional de las humanidades digitales." Janus. Estudios sobre el Siglo de Oro, Anexo 1 (2014): 37-62. доступно преко dialnet.unirioja.es/descarga/articulo/5181017.pdf

7 На мрежним страницама Универзитета Беркли постоји покушај дефинисања дигиталне хуманистике Веновим дијаграмом на коме се свесно избегава помињање хуманиоре, па чак и науке док се све оно што хуманистици заправо није инхерентно али јесте у тренду укључује у ову област. http://digitalhumanities.berkeley.edu/ blog/14/10/06/community-curious-cats-berkeley-dh-working-group

8 Spence, Paul. op. cit. На стр.42 наводи да се на америчким универзитетима делатност дигиталних хуманиста претежно везује за катедре енглеског језика, а на европским за студије историје и класичне студије

9 http://www.humanitiesblast.com/manifesto/Manifesto_V2.pdf 
Различити приступи терминима дигиталног и хуманистике, различито виђење могућности колаборативних и дистрибутивних истраживања, па чак и прагматични циљеви појединаца који се труде да обезбеде финансирање пројеката доводе до обиља тумачења шта дигитална хуманистика јесте (и у још већој мери, које су заправо њене границе) и до таквог обиља публикација на ову тему, која би по Киршенбауму ускоро могла постати засебан жанр. ${ }^{10}$ Неки ову чињеницу користе за доказ кризе идентитета дигиталне хуманистике, други у томе виде инспирацију за повремене духовите опаске попут оне о томе да свету заиста нису потребне нове књиге о Дарвину и нова тумачења појма дигиталне хуманистике ${ }^{11}$. Распон постојећих тумачења толико је широк да му не мањка ни мистификације ни демистификације и иде од тога да се примена дигиталних метода у хуманистици може упоредити једино још са открићем штампе и Новог света ${ }^{12}$, до тога да се тумачи као згодан, политички коректан начин привлачења расположивих фондова у (дотад у великој мери занемарена) хуманистичка истраживања. У пракси се често дигитална хуманистика покушава инкорпорирати у сваку врсту трендова при чему се често занемарује кључно питање да ли је у питању научна дисциплина са колико-толико предефинисаним границама или је у фокусу метода која се састоји у критичком интерпретирању великих количина дигиталних података о најразличитијим продуктима људског стваралаштва. Без обзира на ове дилеме, можемо се сложити са професором Универзитета Јужна Калифорнија Марком Марином да је дигитално тек термин транзиције, привремени додатак у доба када хуманистика постаје зависна од машина и изворно дигиталног материјала. ${ }^{13}$

10 Kirshchenbaum, Matthew "What is Digital Humanities and What is it Doing in English Departments." Debates in the Digital Humanities. Ed. Mathew K. Gold. Minneapolis : University of Minnesota Press, 2012. 3-11.

11 Често се као пример наводи страница на којој се може наћи непрегледан број дефиниција ДX: http://www.artsrn.ualberta.ca/taporwiki/index.php/How_do_you_define_Humanities_ Computing__Digital_Humanities\%3F

12 Из прве реченице можда најчешће цитиране књиге из области дигиталне хуманистике: Burdick, Anne et al. Digital humanities.- Cambridge: MIT Press, 2012 стр. VII

$13 \mathrm{http}: / /$ dhdebates.gc.cuny.edu/debates/text/4: „A name that marks a moment of transition; the current name for humanities inquiry driven by or dependent on computers or digitally born objects of study; a temporary epithet for what will eventually be called merely Humanities" 
Уз препоручљив опрез према свим дефиницијама, не смемо занемарити чињеницу да се хуманистичке науке заиста налазе у дуготрајној кризи, проузрокованој превасходно стањем у науци и образовању и општим стањем у друштву које доводи до сталног кресања буџета за истраживања у овој области. Оваква ситуација превасходно је производ корпоратизације универзитета, која је довела до тога да се вредност високог образовања исказује искључиво у економским терминима. Зато је разумљиво што се од брака са новим врлим дигиталним окружењем очекује својеврсна ренесанса интересовања за хуманистичке науке, које реципрочно утичу да дигитална истраживања и дигитални формати добију облик примеренији људској природи. ${ }^{14}$ 3бог стања на тржишту рада, како у развијеним, тако и у мање развијеним срединама, све се мање студената опредељује за студије језика и књижевности, а примене нових апликација доприносе њиховој видљивости и атрактивности. Будући да дигитални свет фаворизује демократизацију културе, омогућава учешће у различитим врстама истраживачких активности, мења начин наставе и олакшава интердисциплинарну сарадњу, његов улазак у поље хуманистике можда је једини начин да хуманистичке (а и друштвене) науке уопште опстану, обезбеђујући довољан број уистину квалитетних истраживачких кадрова и финансијска средства за њихов рад.

Имајући целокупан поменути контекст у виду, запитали смо се о могућностима академских библиотека да своју делатност прилагоде новим трендовима у области хуманистичких истраживања и о улози коју библиотекари имају и зашто им је у манифестима дигиталне хуманистике додељено тако важно место ${ }^{15}$. Покушали смо да анализирамо тренутне начине повезаности библиотека са научно-наставним

14 О међусобном утицају дигиталног окружења и хуманистичких истраживања говори између осталих у раду II Digitale puo salvare la cultura?: ragionamenti e desperienze sull' informatica umanistica професорка Универзитета у Пизи и ауторка подкаста Historycast Енрика Салватори. Рад је доступан преко презентације и снимка са конференције: http://www.slideshare.net/trapelicino/il-digitale-pu-salvare-la-cultura-ragionamenti-sullinformatica-umanistica, https://www.youtube.com/watch?v=pBLchMfDB5M

15 Вранеш, Александра" Дигитална хуманистика и савремене библиотеке." Инфотека $15,1(2014): 4-15$ 
јединицама чији је примарни циљ истраживање у области дигиталне хуманистике.

Хибридна природа савремених библиотека и рана појава дигиталних садржаја у њиховим фондовима и дигиталних ресурса у њиховим физичким и виртуелним просторима довеле су до проширења компетенција у струци баш у правцу на који се нова очекивања надовезују. Стална стручна усавршавања која су организовала или бар финансијски подржавала библиотечка удружења допринела су просечно високом степену познавања опрема и алата; способности креирања и коришћења метаподатака; претраживања база података, али и њиховог креирања и управљања, и коначно, знања из области права, технике и организације релевантних за деловање у дигиталном окружењу. Подједнако је била важна стабилност и институционални карактер библиотека који је од њих начинио ентитет довољно добро позициониран у оквиру универзитета да буде у стању да обједини разнолике облике деловања дигиталних хуманиста. У том смислу, библиотеке су јачале своју партнерску улогу кроз пројекте у време када су они доминантни извор финансирања а упоришне тачке ${ }^{16}$ су биле:

1. Стандардизација пројектне документације из различитих области без које није могуће обезбедити одрживост пројеката. Учешћем библиотечких стручњака у раду на пројектима у иницијалној фази обезбеђивала се техничка доследност у области стандарда и метаподатака неопходних за очување резултата пројеката.

2. Садржинска обрада пројектне документације омогућава лакшу и транспарентнију евалуацију, а важна је и за доказивање њене аутентичности.

3. Обезбеђивање дугорочне доступности докумената, будући да је управо ефемерност продукције - поготово у фази пре рачунарства у облаку, али и касније- кључни проблем. Библи-

16 Идентификација ових упоришних тачака ослања се на чланак Galina Russell, Isabel. "The role of libraries in digital humanities". World Library and Information Congress: 77th IFLA General Conference and Assembly. 2011 http://conference.ifla.org/past/ifla77/104russell-en.pdf. 
отеке најчешће проналазе најефикасније начине дугорочног даљег коришћења резултата истраживања свих научних области, укључујући и хуманистичке науке. Институционални карактер и стабилност библиотека у оквиру универзитета најчешћа су полиса осигурања истраживача да ће њихов рад бити дугорочно доступан и да се неће злоупотребљавати без последица.

4. Допринос библиотека евалуацији резултата истраживања огледа се двојако: укључивање у библиотечку колекцију даје додатну вредност пројектима; а такође је могуће да библиотекари дефинисањем одговарајућих индикатора за скоровање буду укључени у евалуацију.

5. Укључивање резултата истраживања у библиотечке портале, репозиторијуме и каталоге обезбеђује повећање видљивости резултата истраживања појединачнихпројеката, те њихово веће коришћење и праћење тог коришћења преко цитирања. Наиме, пуко постављање ресурса на мрежу није гаранција њихове видљивости.

Велики број универзитета у свету је у оквиру својих библиотека основао наставно-научне дигиталне центре за подршку науци, учењу и подучавању, од којих неки покривају широк спектар научних дисциплина, а неки су специјализовани само за хуманистику. Од традиционалних истраживачких институција ове центре разликује инсистирање на најактуелнијим дометима информационо-комуникационих технологија. Они се међусобно разликују по величини, активностима, финансирању, особљу и обиму истраживања, али уопштено се могу описати као ентитети у којима се нови медији и технологије практично примењују у хуманистичким истраживањима преко модела "sandbox“ и „инкубатор“ за тестирање идеја и технолошких решења - као нека врста зоне за експерименте и иновације, која је све учесталија чак и у области дигиталне уметности јер отвара могућности за нове облике изложби и сарадње међу уметницима, критичарима и историчарима уметности.

Увидом у актуелну праксу преко истраживања постојећег стања на мрежи установили смо да су дигитално-хуманистички центри 
- од којих је већина бар изворно настала у библиотекама а добар број још увек функционише као њихов део - места на којима данас почива развој дигиталне хуманистике. Будући да није било могуће направити ни исцрпан ни нормативан преглед праксе за ову прилику, тежили смо да обухватимо бар неке доминантне моделе и нека занимљива решења, свакако имајући у виду да буду примењиви у условима у којима функционишу академске библиотеке у Србији, али су укључени и неки врло амбициозни модели као подстрек да се обезбеди институционална подршка вишег нивоа.

Најпре смо се запитали да ли су институције које су родоначелници (или претече) дигиталне хуманистике и даље једнако релевантне, и одговор је потврдан и у случају Универзитета Браун на коме је шездесетих година настао Корпус Браун, и у случају Универзитета Оксфорд на коме је први текстуални архив основан захваљујући постојању првог програма оптичког препознавања знакова. Библиотеке обе поменуте институције укључене су у рад центара за дигиталну хуманистику универзитета. При Универзитетској библиотеци Бра$\mathrm{yH}^{17}$ постоји Центар за дигиталну подршку са деветоро запослених који обезбеђују помоћ, између осталог, у домену обраде података, визуелизовања резултата истраживања, учествовања у радионицама и конференцијама, обезбеђивања финансијских средстава уз сталне консултације и повремене организоване обуке. Библиотека Бодлеана, са друге стране, један је од пет конститутивних делова Центра за дигиталну хуманистику Универзитета Оксфорд ${ }^{18}$ и задужена је за организацију предавања која се тичу информацијских вештина неопходних за квалитетан истраживачки рад у овој области, отворених за целу академску заједницу.

О томе да библиотеке нису увек укључене у пројекте дигиталне хуманистике сведочи пример мексичке мреже дигиталне хуманистике Red $\mathrm{DH}^{19}$, која библиотекаре укључује тек симболично, а ипак има запажену улогу у институционализацији дигиталне хуманистике као дисциплине и организовању дигиталних ресурса за

\footnotetext{
17 http://library.brown.edu/cds/

18 https://digital.humanities.ox.ac.uk/about

$19 \mathrm{http}: / /$ humanidadesdigitales.net/
} 
истраживаче. Ова мрежа обједињује универзитетске електронске ресурсе преко заједничког портала и подржава различите видове комуникације међу истраживачима. Степен њене међународне активности је такав да је била важна подршка овогодишњем светском сусрету Викиманије у Мексику а поверено јој је и учешће у организацији Конфреренције Алијансе организација дигиталне хуманистике за 2018. годину ${ }^{20}$.

Универзитет у Лондону 2013. подржао је оснивање центра за електронско издаваштво при библиотеци превасходно намењеног издањима из хуманистичких наука ${ }^{21}$. Искуство које је библиотека пружала у смислу услуге веб-хостинга за електронске часописе у слободном приступу током претходне деценије искоришћено је за техничко оспособљавање, а направљен је финансијски одржив издавачки план који подразумева могућност слободног приступа свим електронским издањима.

Један од најбољих примера интегрисаног референтно-истраживачко-технолошко-едукативног центра јесте Центар за дигиталну хуманистику библиотеке Батлер ${ }^{22}$, једне од библиотека Колумбија универзитета који функционише као део библиотечког Одсека за хуманистику и историју са главним задатком да наставницима и студентима помогне да инкорпорирају дигитални материјал у истраживање, учење и наставу. Осим тога, за студенте се организује едукација и упознавање са најновијим технологијама и електронским изворима кроз демонстрације, радионице и индивидуалне консултације.

Интердисциплинарни истраживачки центар за дигиталну хуманистику Принстон универзитета ${ }^{23}$ конституисан је као јединица Библиотеке. Најзанимљивији пројекти реализовани у овом центру су Принстонов архив прозодије и Фонопост. Први је заснован на формирању базе од преко десет хиљада дигитализованих и у целости претраживих текстова тумачења поезије насталих у периоду од 1750 до 1923. године, на основу које се реконструишу технике читања кроз различите историјске епохе. Фонопостов онлајн архив састоји се

20 Alliance of Digital Humanities Organizations (ADHO), http://adho.org/conference http://www.ucl.ac.uk/ucl-press http://library.columbia.edu/locations/dhc.html The Center for Digital Humanities (CDH). https://digitalhumanities.princeton.edu/ 
од изразито фрагилне аудио-визуелне грађе која је подложна брзом испаравању, попут приватних снимака првих аудио порука које су слате преко компјутера као акустична писма. Пројекат

функционише кроз сарадњу са Слободним Универзитетом из Берлина, а истраживања на овим материјалима финансира Фондација Ајнштајн из Берлина. Из његовог електронског издавачког корпуса издваја ce Short Guide to the Digital Humanities - кратак, информативан и користан увод у главна питања дигиталне хуманистике. ${ }^{24}$

Центар за дигиталну хуманистику Универзитета Калифорнија у Лос Анђелесу који функционише под геслом: „Проширимо домет и утицај хуманистичких наука за јавно добро“25, један је од најбољих примера интердисциплинарног и колаборативног приступа. У рад центра непосредно је укључено чак тридесет пет факултета и двадесет департмана, као и централна библиотека универзитета. Почетком 2015. године у сарадњи са Одсеком за шпански и португалски језик Универзитета Калифорнија покренут је занимљив пројекат Story Maps for the humanities који је усмерен на проучавање шпанског језика у области Лос Анђелеса да би се описао диверзитет језика у датом ареалу, уз богати аудио и видео материјал.

Центар у оквиру Универзитета Калифорнија у Берклију ${ }^{26}$ кога финансира Мелоун фондација покренуо је велики број разнородних и врло амбициозних пројеката. Бројгелова породица располаже базом од преко 500 дигитализованих оригиналних Бројгелових радова који се компјутерском техником пореде са више стотина дигиталозованих копија и варијанти, док Шекспирова позорница истражује историју позоришног представљања Шекспирових комада преко слика, гравира, фотографија, видео-записа, есеја и библиографија. Лабораторија за испитивање предмета материјалне културе старог Рима Res Romanae подржава пројекте из ове области, а Будућност памћења истраживања јеврејске културе у дигиталном добу. Правилник овог центра садржи клаузулу да се у сваки пројекат мора укључити један представник Универзитета и један члан изван академске заједнице (најчешће библиотека).

24 http://jeffreyschnapp.com/wp-content/uploads/2013/01/D_H_ShortGuide.pdf

25 http://www.cdh.ucla.edu/ „Expanding the reach and impact of the humanities for the public good"

26 http://digitalhumanities.berkeley.edu/ 
Импозантан број специјализованих база података и дигитализованих средњевековних извора, расутих на различитим оперативним системима и платформама широм Француске довео је до замисли о специјализованом порталу Biblissima ${ }^{27}$ у коме учествује низ партнера. Превасходни задатак јесте формирање јединственог корпуса материјала и могућност контрастивне анализе свих средњевековних и ренесансних извора који би били доступни заинтересованим истраживачима на једном месту. Пројекат је због своје комплексности и амбициозности подељен на две фразе реализације (техничко оспособљавање упрвој и имплементација и популаризација у другој), паралелно обезбеђујући подршку различитим конкретним пројектима из ове области. Ради стандардизовања визуелних база података, ито је један од кључних циљева овог пројекта, овог лета је формиран глобални конзорцијум Међународни оквир за интероперабилност визуелне грађе, ${ }^{28}$ у коме она учествује преко Националне библиотеке Франиуске.

Иницијатор поменутог конзорцијума, поред британске националне библиотеке и библиотеке Бодлеана јесте библиотека Универзитета Станфорд - чије разноврсно деловање у области дигиталне хуманистике заслужује посебну пажњу.

У оквиру Станфордовог центра за дигиталну хуманистику ${ }^{29}$ реализован је читав низ занимљивих пројеката из ове области, који су добар пример конкретне примене дигиталног материјала и техника у области хуманистике. Forma Urbis Romae коришћењем GIS технологије креира слојевиту представу античког града Рима на основу карте анонимног аутора из 1901. на коју се надограђују сва археолошка истраживања током 20. века; Orbis визуелизује транспорт људи и добара у Римском царству; Природа града преконструише градове предвиђајући њихов развој у скоријој будућности, а његове Лакуна приче пружају могућност коришћења интерактивног истраживачког форума намењеног проучавању конкретних политичких или историјских питања која се сматрају спорним на различитим ни-

\footnotetext{
27 http://www.biblissima-condorcet.fr/

28 International Image Interoperability Framework (IIIF), http://iiif.io/

29 https://digitalhumanities.stanford.edu/
} 
воима (међу којима се нарочито истиче 9/11) у настојању да се попуне празнине у њиховом тумачењу.

Посебно место у Станфордовом центру има Књижевна лабораторија - The Stanford Literary Lab ${ }^{30}$ - истраживачки центар где се у студијама књижевности примењује компјутерска критика, тако што се квантитативно истраживање узима као основ тумачења књижевности. Деловање Франка Моретија, једног од оснивача Стандрордове књижевне лабораторије и контроверзног заступника радикалне теорије читања из друге руке (distant reading), најбољи је пример ћорсокака дигиталне хуманистике, заглављене у идеологији искључивања вредносног суда при разумевању и интерпретацији књижевности. Супротстављајући се Гетеовом схватању светске књижевности као скупа репрезентативних дела свих народа, то јест врхунског стваралаштва свих епоха и језика - Морети заступа став да сва икада и игде написана дела имају исту вредност, те да је потпуно свеједно да ли ћемо читати Хомера, Шекспира, Сервантеса, Толстоја, или пак непозната дела анонимних аутора исте епохе и жанра. Па имајући то у виду, он предлаже да се уопште ни не читају књижевна дела већ да се на основу корпуса компјутерски обрађених дела истог жанра (у његовом случају романа као „планетарне форме“) формира нека врста интерпретативних образаца као основа књижевних изучавања. По њему, дакле, разумевање књижевности не проистиче из помног читања, студирања и анализе појединачних дела (close reading), већ из агрегације и нумеричке анализе масивне количине података. ${ }^{31}$ Моретијев пример показује да је глорификација технологије и њених метода квантификације и мерења, тако неопходних у бирократији и привреди, заправо врло често антитеза ономе што је суштинско интересовање хуманиста. Чак и када су компјутерски програми пројектовани тако да могу на основу морфолошких, лексичких и синтаксичких својстава да одреде аутора текста са већом или мањом сигурношћу, прилично је извесно да нам не говоре баш ништа о естетској вредности текстова нити идејама које је аутор из-

\footnotetext{
30 https://litlab.stanford.edu/

31 Moretti, Franco. "Conjectures on World Literature" New Left Review 1 (Jan.-Feb. 2000):54-68 http://newleftreview.org/II/1/franco-moretti-conjectures-on-world-literature
} 
разио. У том смислу можемо закључити да - бар на тренутном нивоу технолошког развоја вештачке интелигенције - интерпретација и критичко мишљење ипак остају основни алат и оружје сваког правог хуманисте, а индивидуална истраживачка позиција природно и можда једино могућно стање за ову врсту тумачења.

Упркос својој, по много чему специфичној позицији реномираног приватног универзитета који не пати од проблема финансирања, ваља истаћи да и Станфорд бележи пад интересовања за хуманистичке студије, те да се за њих пре две године опредељивало тек петнаест процената нових студената, па је због одрживости студијских програма морао бити преиспитан њихов курикулум. ${ }^{32}$

Питање финансирања рада у области дигиталне хуманистике једнако се намеће и приликом анализе улоге и учешћа библиотека у њеном развоју. Стога се мора напоменути да се оно заправо не мора заснивати на пројектима, већ може бити и сасвим самостално, у оквиру буџета саме библиотеке или универзитета коме припада. У том смислу може се навести пример портала Маниок Универзитета Антила и Гвајане ${ }^{33}$. Комплетна реализација овог портала кренула је од нуле, тражена су оригинална техничка и графичка решења, а финансирање је ишло сукцесивно, најпре самостално из буџета саме библиотеке, а затим преко уговора о сарадњи са различитим институцијама.

Финансирање може бити реализовано и организованим прикупљањем средстава путем кампање. При њеном организовању неопходно је обезбедити транспарентност и истаћи једноставну рачуницу која говори у прилог овој врсти друштвено одговорног пословања. Тако Версајски универзитет на својим мрежним страницама јасно истиче могућност пореских олакшица за све врсте донатора при чему се у појединим случајевима на уплаћених 1000 евра, порез умањи за чак 750. ${ }^{34}$

Најређи случај финансирања јесу појединачни велики донатори, најчешће фондације. Занимљив је пример релативно малог Универзитета Вашингтон-Ли из Лексингтона чије програме у обла-

32 http://www.nytimes.com/2013/10/31/education/as-interest-fades-in-the-humanitiescolleges-worry.html?_r=0

33 http://www.manioc.org/

34 http://www.fondation.uvsq.fr/fiscalite-reconnaissance/ 
сти дигиталне хуманистике ${ }^{35}$ обилато финансира фондација Мелоун. У питању је универзитет са пет факултета који годишње прими 455 бруцоша, од којих скоро половина користи неку стипендију. Јуна ове године овај универзитет је добио донацију Фондације Ендрјуа Мелоуна од осамсто хиљада долара, намењену искључиво педагошким иновацијама у области дигиталне хуманистике: организовању предавања, проширењу особља, сарадњи са другим институцијама, учешћима на радионицама и конференцијама.

Да резимирамо, деловање центара дигиталне хуманистике, без обзира да ли су у библиотекама или ван њих, одвија се кроз неколико главних активности:

1. Планирање дигиталнихпројекатаиподршкатоком реализације

2. Различите врсте обуке за коришћење специјализованих софтвера и алата за истраживања у овој области,

3. Развијање одговарајућих база података,

4. Стварање колаборативне платформе за научну сарадњу,

5. Правно-финансијска подршка истраживачима.

Што се тиче Универзитетске библиотеке „Светозар Марковић“, дигиталне хуманистичке науке присутне су од 2011, преко портала ${ }^{36}$ и репозиторијума Универзитета у Београду ${ }^{37}$ као потенцијалних извора грађе за истраживања. Основни правци деловања вероватно ће бити усмерени на баштину, конкретне пројекте сарадње и подршку научној продукцији у области дигиталне хуманистике.

35 https://digitalhumanities.wlu.edu/devel/

36 http://www.unilib.rs/sadrzaji/digitalna-humanistika/ „Библиотека организује предавања из области дигиталних хуманистичких наука, преводи текстове који су у слободном приступу и чини их доступним путем наменски креиране веб странице. Представљени су и текстови који нису у слободном приступу, а који су доступни у библиотеци, путем рецензија и приказа. Сви заинтересовани чланови академске заједнице Србије добродошли су у овом подухвату који кроз сарадњу унапређује коришћење информационих и комуникационих технологија у области хуманистичких наука."

37 http://www.unilib.rs/sadrzaji/phaidra/„PHAIDRA чува податке потребне за истраживачки, наставни и организациони рад на Универзитету. Она омогућава управљање подацима, флексибилно коришћење ресурса, лоцирање и проналажење похрањених дигиталних објеката. Дигитални репозиторијуми на транспарентан начин сведоче о досегу и опсегу научног рада на универзитету и повећавају његову видљивост на вебу. Репозиторијум PHAIDRA један је од резултата Темпус пројекта Нови библиотечки сервиси на универзитетима Западног Балкана." 
Када је баштина у питању, поред укључивања дигитализоване грађе у опште колекције под окриљем националних и међународних пројеката, акценат ће у наредном периоду вероватно бити на историји српске науке и архивској грађи Универзитета у Београду, ради учвршћивања везе са кровном институцијом. Такође је препоручљиво колаборативни приступ проширити са сарадње са институцијама: факултетима, институтима, архивима, сродним библиотекама - на сарадњу са појединцима: научницима, професорима, студентима - чиме ће се обезбедити директно учешће у индивидуалним пројектима.

У сваком случају, уколико се жели обезбедити учешће у било којој врсти пројеката који се тичу дигиталне хуманистике, неопходан је сталан рад на побољшању инфраструктуре, уз сукцесивно проширивање репозиторијума. Угледу установе свакако би допринело отварање могућности веб-хостинга за научне институције ван Универзитета у Београду, формирања корпуса на захтев и електронског издаваштва научних радова отвореног за све заинтересоване појединце и институције. Имплементација постојећих и будућих униформних платформи за различите врсте грађе и превођење из старих у нове носиоце информација, очување резултата истраживања по окончању пројеката такође су смернице по којима би Универзитетска библиотека требало да се управља, по узору на друге библиотеке.

Обим сарадње и са појединцима и са институцијама мериће се управо капацитетом библиотеке у области организације, интелектуалног власништва, управљања информацијама и техничким могућностима за дигитализацију и визуелно представљање података. Оно што не смемо притом заборавити јесте професионални и стручни ниво библиотекара од којих се за рад у домену дигиталне хуманистике, данас захтевају компетенције у мноштву различитих области, поред основног хуманистичког образовања које се подразумева. Један од најбољих примера је конкурс за позицију библиотекара за истраживања у дигиталној хуманистици са стандардним радним временом универзитета Јејл. У њему се поред основног хуманистичког образовања тражи познавање дубинске анализе података, њиховог кодирања и техника и метода за анализу текстова, искуство 
у раду са ГИС технологијом, познавање теорије графова и графичких аналитичких алата попут ГЕФИ програма, познавање алата за статистичке прегледе, визуализацију података, релационе базе података, развој серверских скриптова и примена слободних софтверских оперативних система. ${ }^{38}$ Од централне универзитетске библиотеке свакако ће се очекивати да организује обуку за ове и сличне стручне компетенције за све високошколске библиотекаре и за онај део истраживачке заједнице коме је хуманистика још увек ближа одредница него дигитално окружење у коме ваља делати. Сасвим је извесно да се и поред тих напора на листи најтраженијих послова неће наћи (а вероватно ће тако и остати) послови везани ни за традиционалну ни за дигиталну хуманистику, па ни за библиотекарство.

Промоцијатрајниххуманистичкихвредностиусведоминантнијем дигиталном свету; стално прилагођавање новим захтевима истраживачке заједнице, али и њихово предвиђање; развој едукативних програма и тестирање педагошких иновација (што је захтеван посао коме се још нисмо ваљано посветили) - то су неки од задатака које себи мора да постави централна библиотека Универзитета у Београду. За тако нешто потребно је ангажовање широког спектра стручњака (од којих они са хуманистичким образовањем не смеју бити мањина) чије се додатно образовање мора брижљиво планирати. Квалитетно удруживање са партнерима из владиног и невладиног сектора, укључујући најразличитије фондације, донаторе, медије, друштвено одговорне профитне компаније додатно ће учврстити уцртану трасу по којој би библиотека обезбеђивала низ оперативних сервиса за целу академску заједницу унапређујући на тај начин наставни и научно-истраживачки процес на универзитету.

\section{Библиографија}

Barret, Elydia. Quel rôle pour les bibliothèques dans les humanités numériques http:// www.enssib.fr/bibliotheque-numerique/notices/64711-quel-role-pour-lesbibliotheques-dans-les-humanites-numeriques. 07.09.2015.

38 https://collaborate.library.yale.edu/lhr-public/jobs/digitalhumanities.aspx 
Burdick, Anne et al. Digital_Humanities. Cambridge, MA: MIT Press, 2012

A Digital Humanities Manifesto http://manifesto.humanities.ucla.edu/2008/12/15/ digital-humanities-manifesto/ 07.09.2015.

The Digital Humanities Manifesto 2.0 http://www.humanitiesblast.com/manifesto/ Manifesto_V2.pdf 07.09.2015.

Gold, Mathew K. Ed. Debates in the Digital Humanities. Minneapolis: University of Minnesota Press, 2012

Galina Russell, Isabel. "The role of libraries in digital humanities". World Library and Information Congress: 77th IFLA General Conference and Assembly. 2011 http:// conference.ifla.org/past/ifla77/104-russell-en.pdf.

Spence, Paul. "Centros y fronteras: el panorama internacional de las humanidades digitales". Janus (2014) dialnet.unirioja.es/descarga/articulo/5181017.pdf 07.09.2015.

Вранеш, Александра. “Дигитална хуманистика и савремене библиотеке." Инфотека 15,1 (2014) : 4-15

\author{
Nataša Vasiljević \\ Vuka Jeremić \\ University Library "Svetozar Markovic" \\ Belgrade
}

\title{
LIBRARY AND DIGITAL HUMANITIES: INTERACTIONS AND PERSPECTIVES
}

\section{Summary}

After the brief terminological and theoretical review of various library activities that advance scientific work in the field of digital humanities, this paper presents some examples of such library engagement which have dominated during the last ten years. This kind of activity in libraries is primarily developed through various forms of program and project collaboration with other scientific institutions, often focused on the cultural heritage preservation, rather than creating original scientific papers, or promoting scientific and teaching process.

The paper examines the ways in which the University Library "Svetozar Markovic" so far has participated in projects that are directly or indirectly related to the field of 
digital humanities, as well as those that can be implemented in the current, relatively unfavorable circumstances, in order to increase the quality of services and also to strengthen links with the university community. Having regard to the sustainability of projects in the real social and academic environment and modern trends of scientific-research activities, authors recommend several models that include the rational use of existing resources and purposeful creation of new ones, together with permanent redefinition of priorities, and parallel engagement in the Library and beyond.

Key words: libraries, digital humanities, data mining 